\title{
The Early Childhood Workers Union: an analysis of collective conciousness and praxis.
}

\author{
Helen Cook*
}

This article discusses the problems of forming a union and raising union consciousness among women working in childcare centres. The article also discusses social attitudes to childcare and childcare workers and the problems this poses in union organisation.

The Early Childhood Workers Union (ECWU) was registered in March 1982. It was: a union for up to 2000 women childcare workers, whose collective voice was to bring a new "front" to the on going politics of childcare in New Zealand; a union that had been initiated by the energies and vision of Sonja Davies, who willed, cajoled and enticed reluctant childcare workers to do something for themselves about their appalling wages and conditions of work; a union without an award, that became an aggrieved and newsworthy anomaly amidst the wage-price freeze regulations that prevented award negotiations. In this union, which was established amidst tentative enthusiasm, naivety, and indeed apathy, there began to emerge a transformation in consciousness, and a new activism.

Helen Cook, the National President, was to say in an interview one year after registration:

These early battles have meant the union's public profile has been higher than anticipated.

Our image has been strident and radical ... But we've got to shout loudly to be heard.

(NZ Listener, 7 May 1983).

Paulo Freire (1972) writes that the transformation of people from being Objects, with no power to determine their lives, to become active Subjects in the process of living, requires, ". . the people to act, as well as reflect upon the reality to be transformed." (p.101). The "reflection upon reality" is part of the process of consciousness raising, whereby people become aware that their oppressive experiences are not necessarily individual experiences, but are shared collectively, and can be analysed within a political and theoretical framework. A changing consciousness is an essential part of the process of political and social change. The transformation of such oppressive realities also requires the theoretical complement to new consciousness - praxis; the dialectical process of critical reflection and action, or, in Marx's view, unity of theory and practice, whereby the task of philosophy was not merely to comprehend reality but to change it. ${ }^{1}$ In Freire's usage of this marxian concept, becoming an active and conscious Subject in a transformed reality requires the praxis of the people who are themselves the Objects of oppression: "they must be Subjects of the transformation" (Freire, 1972, p.97).

This paper is an analysis of the ECWU in the context of: the relationships surrounding the oppression of childcare workers; the submerged consciousness of the childcare workers as Objects; the emergence of a new consciousness and praxis amongst childcare workers

* President, Early Childhood Workers Union.

1. For further elaboration of the concept "praxis" see Colletti (1975) and Freire (1972). 


\section{Helen Cook}

as active Subjects: and the beginnings of a transformation in the politics of childcare in New Zealand.

There has always been a need for childcare services, but it has existed on the "underside" of early childhood education; as an uneasy contradication to the ideal values concerning the role of men, women, the community, and the State towards the care of children. The childcare service, beyond it's "crisis-care" function has been threatening as an alternative to the "ideal" model of childrearing. It explicitly enables more women to be part of the workforce, and it potentially challenges the power relationships within the home, the community, and the State.

The contradiction between the myth and reality of childrearing, has made childcare an issue in which there is exhaustive lobbying for and against. Geraldine McDonald lists the parties to the dispute as including:

The established pre-school movement, the childcare movement, the Government Departments of Health, Education and Welfare, women's groups of differing persuasion, employers, employee organisations, "experts" in child development and care, and men, political parties and "society at large" (1978, p.71).

On the other hand Anne Smith claims that:

The vast majority of childcare workers are unconcerned with politics. They enjoy working with children and do not want to be bothered with matters of public policy. Similarly parents, although they usually want their children to be cared for well, are often pre-occupied with other events of their daily lives $(1981$, p.3).

Until one is conscious of childcare as existing in a wider network of relationships it is usually perceived as non-political. "We need to discover problems hitherto believed to be personal are in fact social and to fight against them is political" (Guettal, 1974 p.61). Any transformation in the relationships surrounding childcare demands not only a consciousness of the power relationships operative within the political and economic structures of our society, but that the private world within the family and home also be discovered as political.

The submerged and oppressive relationships that have surrounded childcare workers exist within a microcosm but one that cannot be separated from the macrocosm of the wider politics of childcare; an arena that challenges the patriarchal structures embedded throughout the fabric of our society. Working in childcare has by tradition been a lowstatus occupation, and, even in the sphere of early childhood education childcare workers have fared poorly in comparison to kindergarten teachers; despite doing the same work, the care and education of children. The kindergarten however, with its part day "educational" sessions does not challenge existing beliefs and values in the role of the family. Society has accepted, that the mother's role in childrearing can be complemented by parttime pre-school educational sessions, but it is still reluctant to acquiesce in the support of any service which is seen to relieve women of some of the "caring" functions of motherhood, except in circumstances of incompetence or crisis.

On the other hand, childcare workers and kindergarten teachers collectively in the sphere of early childhood education have lower status in terms of pay and conditions of work than the other echelons of the education service. This is despite the fact that the early childhood years have long been recognized as the most formative years in a persons development. Because of its close alignment with "mothering and caring" early childhood education has always been seen as fulfilling custodial, emotional, or social needs, as opposed to the presumed intellectual functions of the rest of the educational system; a division which is both arbitrary and inaccurate.

Unlike other occupational groups that are predominantly within the woman's "sphere", such as cleaners, clothing workers, shop employees and so on, women workers in early childhood education were slow to move towards unionism and collective bargaining structures. The Kindergarten Teachers Association (KTA) was registered in 1958, but only 
within the last decade has it had an effective bargaining voice. The reasons, I suggest, are as follows: First, the strong voluntary and/or charitable component of early childhood education has acted against unionism. Resources from the beginning were scarce, and those workers who were paid saw their cheap labour as a contribution to a service they believed in. Secondly, to work with young children was seen as a suitable "ladylike" occupation for young women, and one that was a good preliminary to motherhood. Shades of these beliefs still remain. Many women have "passed through" early childhood education on their way to marriage and family, with only a few making a long term commitment to a service with little career structure and few material rewards. Thirdly, early childhood workers are not visible as a group. Unlike factory workers, or even city office workers who work within a similiar physical space, early childhood workers are fragmented throughout towns, cities, and suburbs: thus their loyalties tend to be localized.

With extensive Government funding the support in the post-war period, the kindergarten was recognized as the main form of early childhood education in New Zealand, although playcentres, entirely voluntary organisations, grew alongside as an acceptable alternative. The 1947 Bailey Report (Consultative Committee, 1947) which heralded the beginning of increased State involvement in early childhood education, rejected support to all day nurseries on the grounds that young children would be, "deprived of the vital experiences that only the normal home can provide" (p.11). This, however, ignored the reality that many women needed to work, wanted to work, and indeed were being encouraged to work in the new post-war manufacturing industries. As the Government had sidestepped any responsibility towards childcare services, it become a domain of small scale private enterprise, and a few charitable groups. The 1970s saw a growth in nonprofit making community centres, but in all childcare centres financial support came almost entirely from such fees as parents could affort to pay. The 1980 s have seen a certain financial streamlining in the growth of a large charitable childcare chain - Barnado's and the establishment of several profit-making childcare chains, where standardisation is seen to make better business sense. Despite continual financial hardship, the childcare services, in their various forms, have operated, but only because childcare workers have accepted low wages and poor conditions of work. As the Managing Director of Kindercare, New Zealand's largest childcare chain replied recently when asked how salary increases would effect Kindercare: "We'd crumble . . . there is not one person on our staff who I would not like to see get $50 \%$ more : but if we did we'd go down very quickly" (NZ Listener, 7 May 1983).

The collective consciousness of childcare workers was slower to emerge than that of their counterparts in the kindergarten service. Childcare workers, in the past, have felt few common bonds with each other. Unlike kindergarten teachers who undergo similiar training to each other, childcare is something of a "melting pot" with workers from diverse backgrounds and fields of training. There are no formal links between childcare centres and this has hindered the emergence of a common consciousness as childcare workers. Collectively, childcare workers are the lowest paid workers in New Zealand, ${ }^{2}$ but childcare workers themselves experience this oppression as an individual problem stemming from the difficulties of the parents or the employer form whom they work. Such fragmentation has privatised and tivialized what are common issues.

Another counterbalance to collectivism is that, although workers may feel the injustice of their working conditions, their close relationship with the parents through the children makes it difficult to express such frustration; higher pay means higher fees for the parents. The irony is that most childcare workers have felt more akin to the parents at the centre where they work, than to their fellow childcare workers in the next suburb. The conflict has thus remained submerged, and the issues have not been perceived as collective reality or a collective oppression.

2. Childcare workers are the only workers apart from domestic workers without an award. The ECWU's own survey conducted for the Department of Labour in early 1983 showed that the average wage was well below that in any award. 
The transformation of this submerged reality has at last begun. Unlike the KTA, whose model of unionism followed that of the NZEI and the PPTA under the umbrella of the Combined State Unions, the ECWU was registered under the Industrial Relations Act 1973 - a different sphere of politics and activism. Its establishment resulted in a certain polarisation, a consequent uneasiness within the childcare movement, and the emergence of a new arrangement of relationships. Many employers felt threatened, and with the assistance of the Employers Federation some Auckland employers began the process of forming a childcare employers association. Some employers rejected the advice of the Employers Federation who cautioned against recognition of the union, and began negotiation with the aim of regularizing and codifying haphazard work instruments.

Parent users, like childcare workers, have also been a "submerged" voice. It was noted that within centres with strong union membership, parent users rather than feeling threatened by such activism, began to express a cautious support and showed a new awareness of the oppression of childcare workers, and their own unconscious role in this oppression.

The reaction amongst childcare workers themselves, varied: in some areas this resulted in a burst of activism in terms of meetings, discussion of common issues and the formation of branches, discussions with employers, drawing up and negotiation of claims, visiting centres, producing a newspaper: a collective consciousness and praxis became a reality. Much support and advice came from 2 advisors appointed by the Federation of Labour. But with a strong do-it-yourself ethic childcare workers quickly acquired new skills. During this early phase the ECWU has indeed been its members.

Other childcare workers like their employers felt threatened; although often acknowledging their underpaid status they did not want trouble. Some felt they had good conditions and did not need a union for themselves, although union assistance always seemed to be sought when these privileges were threatened. And still for many, the union was seen as remote and not relevant to them. For these workers, the submerged individual consciousness remained paramount.

During 1982 the union began its first negotiations with individual centres but the wageprice freeze prevented both registration of these and any further negotiation. This caused frustration, delay, and threatened the future viability of the union, but it also served to politicize and strengthen the collective consciousness of its members. Again, new skills were learnt by way of political lobbying and media communication, as the union publicly demanded the right to establish initial awards to safeguard the basic rights of childcare workers. In December 1983 the ECWU was granted a limited exemption from the wage freeze regulations in order to negotiate conditions of work (not wages) with willing employers. Because of the uncertain nature of such an agreement the case was referred to the Arbitration Court which has ruled that conciliation may proceed. Any agreement will however cover only those employers who are willing to be bound.

As a complement to this activism from the ECWU, there was also a transformation beginning in the politics of childcare. The decade has begun on a hugh note with the release in 1980, of a Stated Services Commission Report (Early Childhood, 1980) which recommended that there be equitable funding amongst the early childhood education services, with Government contributing up to 50 percent of the cost of childcare. Such optimism was short-lived. The Labour Party, which had promised to implement the recommendations lost yet another election, and in 1982 the National Government shelved the Report. There was an outcry of aggrieved disappointment, but within months the Department of Social Welfare started to construct a funding proposal for limited salary subsidies to childcare workers. Ironically, this was a proposal that would even save money. The Government was feeling sensitive about the continual accusation that, unlike other early childhood services, childcare centres got no direct Government money. They were even more uncomfortable about the overspending and growing usage of parents' childcare fee subsidies. And perhaps too, they were beginning to believe the rumours of poor quality centres, and the evidence that showed a correlation between training, good wages and conditions, and quality childcare. 
A transformation in what had been an intractable front in the politics of childcare was beginning but childcare workers were in an ambivalent situation. On the one hand their need for better training and conditions of work were being acknowledged, by one Departand even acted upon, but simultaneously their union was being prevented by Government regulation from negotiating any change to their existing conditions.

\section{Conclusion}

The ECWU is in its infancy with a still uncertain future. Although the union has provided a theoretical and political framework for a new consciousness and praxis amongst childcare workers, its collective voice is still small, incomplete and weak. Its an effectiveness that has been further constrained by the Government's economic and industrial policies. The transformation of a new consciousness into praxis is a slow process and one that is delicately balanced between increasing determination and commitment, and "burnout" and disillusionment. For union members, there is the complementary feeling, of being powerless Objects against patriarchal structures, and the present industrial politics; at the same time a growing consciousness of becoming active Subjects of transformation within the politics of childcare - a microcosm however, that seems overwhelmed and imbalanced against the power relationships of the macrocosm.

\section{References}

Clark K Cook H and Pearson J (1983) Two models of unionism in ECE : the KTA and ECWU Paper presented to Third Early Childhood Convention, August.

Colletti L (1975) (Ed.) Karl Marx, early writings Harmondsworth, Penguin.

Consultative Committee on Pre-school Education Services (1947) Report Wellington, Government Printer (Bailey Report).

Cook H (1982) Parental praxis : the politics of parent power Paper presented to the Parents Seminar, Hamilton Day Care Centre Trust, October.

Cook H (1983) The politics of childcare : an analysis of growth and constraint Thesis (MA) Victoria University of Wellington, Wellington.

Early childhood care and education (1980) Report of the State Services Commission Working Group.

Freire P (1972) Pedagogy of the opressed Harmondsworth, Penguin.

Guettal C (1974) Marxism and feminism Kitchener, Canadian Women's Educational Press.

McDonald G. (1978) The politics of childcare in New Zealand Research papers '78 Women's studies Hamilton, Women's Studies Association.

Smith A (1981) Dispelling myths about childcare Early childhood quarterly 4(1): 3-7 


\section{R the journal of $\boldsymbol{\Omega} \mathbf{\Omega}$ INDUSTRIAL RELATIONS}

The Journal of the Industrial Relations Society of Australia

Editor: Professor John Niland, University of New South Wales

Vol. 25 No. 4 December 1983

Articles The Impact of Technological Change on Union Structure:

The Waterside Workers Federation

Stephen Deery

The Long-Term Decline in the Standard Working Year John Steinke

The Iron Ore Stockpile and Dispute Acitivity in the Pilbara Chilla Bulbeck

The Operation of Internal Labour Markets: Three Case Studies Margaret J. Nowak and Geoffrey V. Crockett

Towards an Integrated System of Vocational Training:

The Youth Guarantee Concept

W. Merrilees

Of Mountains and Routes Over Them:

A Survey of Theories of Industrial Relations

Braham Dabscheck

Note The 1983 ACTU Congress: Congress Rules OK!

Edward Davis

Address Productivity and Wages Policy

Richard Eggleston

Book Reviews

Published quarterly. Subscription: Australia \$32, overseas \$A38 (surface mail). Single issues: \$A9 (including postage). Order from the Business Manager, Journal of Industrial Relations, GPO Box 4479, Sydney, NSW 2001, Australia. 